\title{
Teaching NeuroImages: Persistent anterograde amnesia due to sequential, bilateral vascular damage to the Papez circuit
}

Fábio H.G. Porto, MD, PhD, Pedro L. de Almeida, MD, and Kirk R. Daffner, MD, FAAN

Neurology ${ }^{\circledR}$ 2019;92:e2838-e2839. doi:10.1212/WNL.0000000000007658
Correspondence

Dr. Porto

portofhg@gmail.com

Figure Acute infarct involving the left hippocampus and nonacute lacunar infarct in the right anterior thalamic nucleus

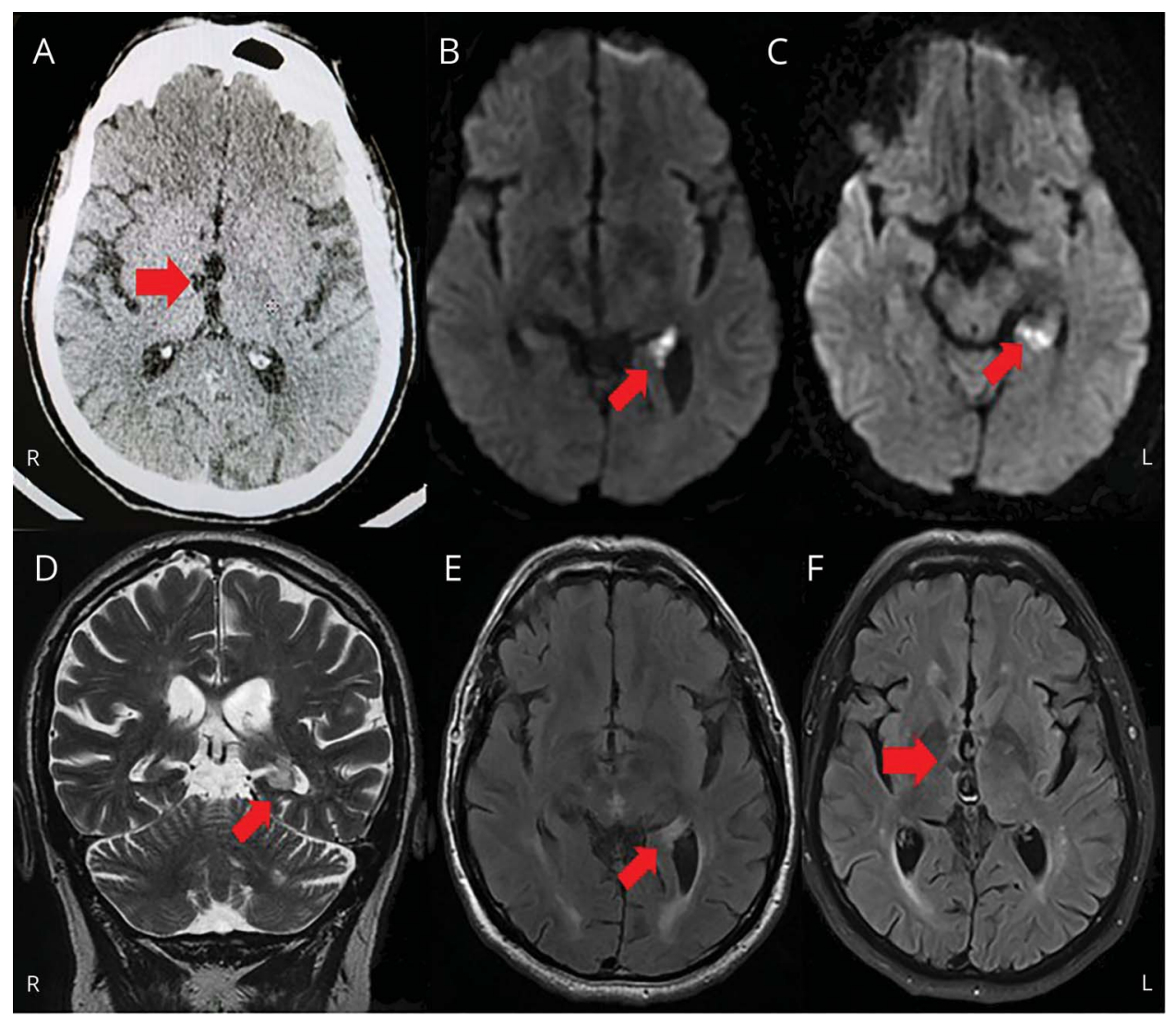

CT performed in the emergency department with a nonacute right thalamic lacune (A, arrow). Axial diffusion-weighted imaging images show hyperintensity in the left posterior hippocampus (B and C, arrows) signaling diffusion restriction. Coronal T2-weighted ( $D$, arrow) and axial fluid-attenuated inversion recovery (FLAIR) (E, arrow) images depict hyperintensity in the left posterior hippocampus. Axial FLAIR (F, arrow) image confirms a large lacunar infarct in the right anterior thalamic nucleus. $L=$ left; $R=$ right.
A 62-year-old previously cognitively intact man presented to the emergency department with acute impairment of anterograde memory (ability to form new memories). ${ }^{1}$ Head CT did not show acute changes; however, amnesia persisted. MRI disclosed an acute infarct in the left posterior hippocampus and a nonacute lacunar stroke in the right anterior thalamus (figure). Memory testing showed severe deficits in verbal and visual memory, persisting after 2 months. Bilateral lesions located anywhere in the Papez circuit (hippocampal formations, mammillary bodies, anterior thalamic nuclei, cingulate and parahippocampal cortices, and their connections via fornix and mammillothalamic tracts) may be implicated in marked, persistent anterograde memory deficits. ${ }^{1,2}$ The hippocampus receives its blood supply from collateral branches of the

\section{MORE ONLINE}

\section{$\rightarrow$ Teaching slides}

links.lww.com/WNL/

A904

From the Laboratory of Psychiatric Neuroimaging (LIM 21) (F.H.G.P.), Department of Psychiatry, Universidade de São Paulo, Brazil; Faculdade de Medicina de Marília (P.L.d.A.), SP, Brazil; and Division of Cognitive and Behavioral Neurology (K.R.D.), Center for Brain/Mind Medicine, Department of Neurology, Brigham and Women's Hospital, Harvard Medical School, Boston, MA.

Go to Neurology.org/N for full disclosures. Funding information and disclosures deemed relevant by the authors, if any, are provided at the end of the article. 
posterior cerebral artery and the anterior choroidal artery. ${ }^{3}$ The anterior thalamus is supplied by the tuberothalamic artery. ${ }^{4}$

\section{Author contributions}

F.H.G. Porto and P.L.de Almeida: study concept and design, acquisition of data, and analysis and interpretation. K.R. Daffner: critical revision of the manuscript for important intellectual content and study supervision.

\section{Study funding}

No targeted funding reported.

\section{Disclosure}

The authors report no disclosures relevant to the manuscript. Go to Neurology.org/N for full disclosures.

\section{References}

1. Gliebus GP. Memory dysfunction. Continuum (Minneap Minn) 2018;24: $727-744$.

2. Aggleton JP, Pralus A, Nelson AJ, Hornberger M. Thalamic pathology and memory loss in early Alzheimer's disease: moving the focus from the medial temporal lobe to Papez circuit. Brain 2016;139:1877-1890.

3. Tatu L, Vuillier F. Structure and vascularization of the human hippocampus. Front Neurol Neurosci 2014;34:18-25.

4. Schmahmann JD. Vascular syndromes of the thalamus. Stroke 2003;34: 2264-2278. 


\section{Neurology}

\section{Teaching NeuroImages: Persistent anterograde amnesia due to sequential, bilateral vascular damage to the Papez circuit}

Fábio H.G. Porto, Pedro L. de Almeida and Kirk R. Daffner

Neurology 2019;92;e2838-e2839

DOI 10.1212/WNL.0000000000007658

This information is current as of June 10, 2019

Updated Information \& Services

References

Subspecialty Collections

Permissions \& Licensing

Reprints including high resolution figures, can be found at: http://n.neurology.org/content/92/24/e2838.full

This article cites 4 articles, 1 of which you can access for free at: http://n.neurology.org/content/92/24/e2838.full\#ref-list-1

This article, along with others on similar topics, appears in the following collection(s):

Assessment of cognitive disorders/dementia

http://n.neurology.org/cgi/collection/assessment_of_cognitive_disorder s dementia

Infarction

http://n.neurology.org/cgi/collection/infarction

Memory

http://n.neurology.org/cgi/collection/memory

Vascular dementia

http://n.neurology.org/cgi/collection/vascular_dementia

Information about reproducing this article in parts (figures,tables) or in its entirety can be found online at:

http://www.neurology.org/about/about_the_journal\#permissions

Information about ordering reprints can be found online:

http://n.neurology.org/subscribers/advertise

Neurology ${ }^{\circledR}$ is the official journal of the American Academy of Neurology. Published continuously since 1951 , it is now a weekly with 48 issues per year. Copyright @ 2019 American Academy of Neurology. All rights reserved. Print ISSN: 0028-3878. Online ISSN: 1526-632X.

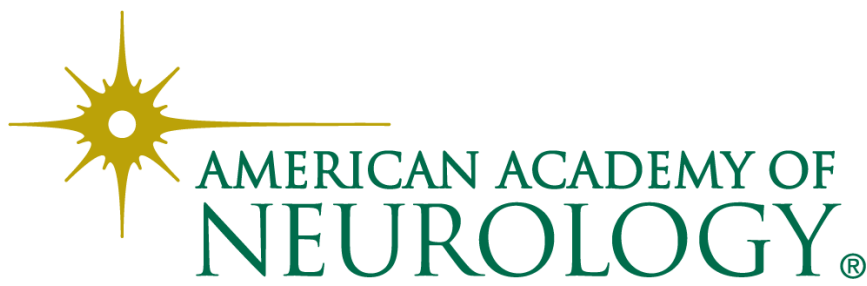

